\title{
Effects of Carvedilol on the Exercise Parameters
}

\author{
Hayder M. K. Al-Kurashiy", Iman N. Abdalwahab*, Ali I. A. Algareeb ${ }^{*}$ and \\ Salahaldun B. Alwindy ${ }^{* *}$ \\ * College of Medicine, Al-Mustansyria University. \\ College of Science, Baghdad University.
}

\begin{abstract}
The aim of this study is to show the effects of carvedilol on exercise parameters. Fifty four volunteers enrolled in this study, 35 males \&19 females. They do exercise on bicycle ergometer, the results was non-significant effects of carvedilol on the exercise unlike other $\beta$-blocker that produce fatigue.
\end{abstract}

Keyword: Carvedilol, Bicycle Ergometer.

\section{Introduction}

Exercise parameters include speed, distance, effort, calori and heart rate, all these can be evaluated by cycling ergometer, during cycling exercise $\mathrm{Vo}_{2}$ max (maximum oxygen velocity consumption) was determined for each subject by incremental exercise test [1].

During the exercise the heart rate increase at least 115 beat/ minute, also plasma adrenaline and noradrenalin showed experimental increase during exercise with threshold of 204-208 watt of cycling ergometer efforts; then plasma adrenaline threshold was lower at the end of exercise [2].

Moreover, the muscle contraction during cycling ergometer produce lactate progressively specially during endurance exercise which cause inverse relation with exercise parameters. During exercise the memory and reaction time improved, this augmented by central nervous system stimulant and carbohydrate consumption [3].

Also there was other type of exercise could influence the exercise parameters, for example moderate altitude and diving but these affect the exercise parameters at different ratio [4].

Hierarchical multiple regression analysis demonstrated that age, number of medication and cognitive speed factor were independent predictor of total performance test score for cycling ergometer regarding a small percentage of variance of physical standardized physical performance test $[5,6]$.

In general, $\beta$-blocker specially nonselective $\beta$-blocker cause peripheral vasospasm due to inhibition of vasodilators $\beta_{2}$ receptor specially at skeletal muscle, all these lead to decrease muscle blood flow specially during exercise leading to tiredness and fatigue [7].

Moreover, alpha blocker did not increase muscle blood flow, because skeletal muscle blood vessels not contain alpha receptor so alpha blocker also produce fatigue due to stagnation of blood in viscera and skin $[8,9]$.

Carvedilol is a nonselective $\beta$-adrenergic blocking agent with alpha blocking activity, no intrinsic sympathomimetic activity has been documented. The associated effects include reduction in cardiac output, exercise or $\beta$ agonist-induced tachycardia, reduction in reflex orthostatic tachycardia, vasodilatation, decreased peripheral vascular resistance specially in standing position, decrease renal vascular resistance, reduced plasma rennin activity and increased level of a trial natriuretic peptide [10].

Carvedilol is rapidly and extensively absorbed following oral administration, which absolute bioavailability of $25-35 \%$ due to significant degree of first pass metabolism. Following oral administration, the apparent mean terminal elimination half life generally ranges from 7-10 hours. Plasma concentration achieved are proportional to the oral dose administrated [11].

Also overdose of carvedilol cause severe hypotension, bradycardia; cardiac insufficiency, cardiogenic shock, bronchospasm, coma and generalized seizure. There is no specific antidote for carvedilol toxicity; but glucagon stimulates the heart by glucagon receptors regardless of adrenoceptor blockade activity of carvedilol it also appear to attenuate oxygen free radical-initiated lipid peroxidation and 
inhibit vascular smooth muscle mitogensis, these effects may contribute to the clinical benefits of the drug in congestive heart failure [12].

Other $\beta$-blockers agent with similar effects is the labetalol which is reversible adrenoceptor atagonist more to $\beta$-receptor but less to alpha receptor, it is not bind to $\alpha_{2}$ receptor, labetalol is not antioxidant like carvedilol [13].

Medroxalol and bucindolo are nonselective $\beta$-receptor antagonist with some capacity to block $\alpha_{1}$ adrenergic receptor [14].

Lipid peroxidation is particularly active during reperfusion of ischemic area causing more free radicals during the exercise, so carvedilol inhibit ischemic injury and free radical formation during exercise $[15,16,17]$.

So in this study carvedilol is selected because it is nonselective $\beta$-blocker with alpha antagonist effect with other effects not related to adrenoceptor like antioxidant effect and nitric oxide donor, so therefore, we can find the effects of carvedilol on exercise parameters that not related to the way of effects.

Therefore the goal of this study is to show; does carvedilol worse the exercise parameters like other $\beta$-blockers.

\section{Subjects and Methods}

In this study, the exercise program consists of cycling on an ergometer (TUNTURI 5835011 Oy, Ltd. Germany). This type of ergometer meet EN precision and safety standard (class A, EN-959-1+5). It allows the user to measure time, pulse, speed, energy consumption, effort, and speed, it display the selected function.

The energy consumption display shows only an approximation of the read consumption. Pulse is measured by using ear pulse sensor. The maximum pulse rate can be achieved in this study.

All the exercise parameters recorded as baseline data, then each subject take opaque gelatinous capsule which contain either placebo or carvedilol $6.25 \mathrm{mg}$ (double blind technique) and after 45 minute, each subject ran on cycling ergometer to exhaustion state, then, the display functions of bicycle were scanned.
Then, the results are expressed as number, percentage, coefficient variation and mean \pm SD. The data analyzed by using student's " $t$ " test (unpaired and paired, two tail) and simple correlation test taking $\mathrm{P} \leq 0.05$ as a lowest limit of significance.

The enrolled subjects were 27 subjects for placebo and 27 subjects for carvedilol, there were 19 females and the remainder was males.

\section{Results}

The result of this study standardized in groups represents the mean, stander deviation, and error for all parameters of cycling ergometer regarding the independent sample student test, the distribution of gender enrolled in this study was higher participation for male regarding the carvedilol and placebo effects so the gender factor not related as dependant factor, (Table (1)).

Table (1)

The characteristics of the study.

\begin{tabular}{||c||c||c||}
\hline \multicolumn{2}{|c||}{ Number } & 54 \\
\hline \multirow{2}{*}{ Gender } & Males & 35 \\
\cline { 2 - 3 } & Females & 19 \\
\hline \hline \multirow{2}{*}{$\begin{array}{c}\text { Age } \\
\text { year })\end{array}$} & Upper limit & 22 \\
\cline { 2 - 3 } & Lower limit & 20 \\
\hline \hline \multicolumn{2}{|c|}{ Range } & 2 \\
\hline \hline \multicolumn{2}{|c|}{ Mean \pm SD } & $21.02 \pm 0.41$ \\
\hline \multicolumn{2}{|r|}{ Heart rate } & $80.50 \pm 21$ \\
\hline
\end{tabular}

Placebo as control produced insignificant effects on all parameters of cycling ergometer $\mathrm{P}>0.05$ Table (2). 
Table(2)

The effect of placebo on cycling ergometer parameter.

\begin{tabular}{||c||c||c||c||}
\hline $\begin{array}{c}\text { Parameter } \\
\text { s }\end{array}$ & $\begin{array}{c}\text { Before } \\
\text { mean } \pm \text { SD }\end{array}$ & $\begin{array}{c}\text { After } \\
\text { mean } \pm \text { SD }\end{array}$ & $\begin{array}{c}P \\
\text { value }\end{array}$ \\
\hline $\begin{array}{c}\text { Time } \\
\text { (minute })\end{array}$ & $6.314 \pm 1.787$ & $6.414 \pm 2.131$ & $>0.05$ \\
\hline $\begin{array}{c}\text { Speed } \\
\text { (m/minute })\end{array}$ & $27.251 \pm 2.127$ & $26.911 \pm 1.112$ & $>0.05$ \\
\hline $\begin{array}{c}\text { Distance } \\
\text { (m) }\end{array}$ & $156.027 \pm 50.811$ & $155.122 \pm 51.201$ & $>0.05$ \\
\hline $\begin{array}{c}\text { Calories } \\
\text { (Kcal) }\end{array}$ & $26.61 \pm 19.011$ & $26.71 \pm 18.112$ & $>0.05$ \\
\hline $\begin{array}{c}\text { Effort } \\
\text { (watt) }\end{array}$ & $72.71 \pm 15.213$ & $72.81 \pm 16.310$ & $>0.05$ \\
\hline $\begin{array}{c}\text { Vo } 2 \text { max } \\
\text { (L/Kg/hr) }\end{array}$ & $19.701 \pm 16.517$ & $18.815 \pm 17.618$ & $>0.05$ \\
\hline Heart rate & $86.71 \pm 18.112$ & $86.77 \pm 17.312$ & $>0.05$ \\
\hline
\end{tabular}

Moreover;carvedilol also produced insignificant effects regarding the cycling ergometer parameters Table (3).

Table (3)

Effects of single oral dose of carvedilol on cycling ergometerparameters.

\begin{tabular}{|c||c||c||c||}
\hline Parameters & $\begin{array}{c}\text { Befor } \\
\text { mean } \pm \text { SD }\end{array}$ & $\begin{array}{c}\text { After } \\
\text { mean } \pm \text { SD }\end{array}$ & $\begin{array}{c}P \\
\text { value }\end{array}$ \\
\hline \hline $\begin{array}{c}\text { Time } \\
\text { (minute) }\end{array}$ & $5.291 \pm 1.891$ & $4.99 \pm 2.713$ & $>0.05$ \\
\hline $\begin{array}{c}\text { Speed } \\
\text { (m/minute) }\end{array}$ & $18.1593 \pm 3.952$ & $18.6593 \pm 2.116$ & $>0.05$ \\
\hline $\begin{array}{c}\text { Distance } \\
\text { (m) }\end{array}$ & $162.41 \pm 32.113$ & $140.33 \pm 13.513$ & $>0.05$ \\
\hline $\begin{array}{c}\text { Calories } \\
(\text { Kcal) }\end{array}$ & $12.70 \pm 1.931$ & $11.56 \pm 2.156$ & $>0.05$ \\
\hline \hline $\begin{array}{c}\text { Effort } \\
\text { (watt) }\end{array}$ & $71.81 \pm 13.152$ & $70.71 \pm 12.151$ & $>0.05$ \\
\hline $\begin{array}{c}\text { Vo } \text { max } \\
(\text { L/Kg/hr })\end{array}$ & $18.813 \pm 13.56$ & $18.701 \pm 11.410$ & $>0.05$ \\
\hline \hline Heart rate & $85.82 \pm 19.122$ & $84.81 \pm 17.192$ & $>0.05$ \\
\hline
\end{tabular}

The efforts of exercise not significantly differed before and after treatment with carvedilol when compared with placebo $(\mathrm{P}>0.05)$.

The descriptive statistics for cycling ergometer before and after treatment with carvedilol using maximum and minimum effects showed marked reduction but not reached to the level of significant $(\mathrm{P}>0.05)$. The pulse before the treatment was $120 \pm$ 10 beat/minute in one occasion but after the treatment with carvedilol the pulse reduced to $110 \pm 5$ beat/minute Fig.(1).

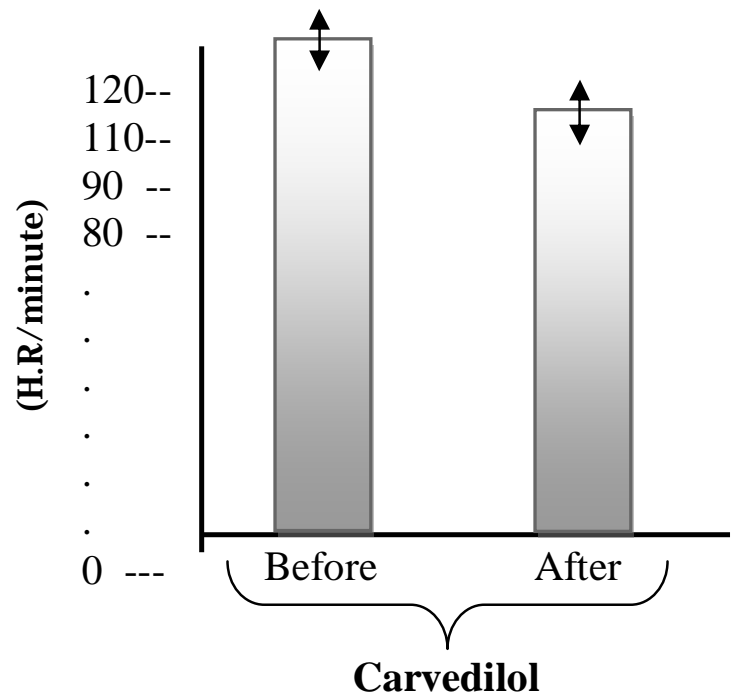

\section{Fig. (1) Effects of single oral dose of carvedilol on the pulse.}

In this study the carvedilol decrease the distance of cycling ergometer from $162.41 \pm$ $32.113 \mathrm{~m} / \mathrm{min}$. to $140.33 \pm 13.513 \mathrm{~m} / \mathrm{min}$. but this not reach to the level of significance $(\mathrm{P}>0.05)$.

Moreover, calori comsumption reduced from $12.70 \mathrm{Kcal} / \mathrm{min}$. to $11.56 \mathrm{Kcal} / \mathrm{min}$., also speed of cycling ergometer minimally increased from $18.1593 \mathrm{~m} / \mathrm{min}$. to $18.6593 \mathrm{~m} / \mathrm{min}$.

From these results, which perse showed that carvedilol don't produce any significant effects on exercise parameters when regarded the significance value was $(\mathrm{P}<0.05)$ so carvedilol not produce decremental fatigue during the exercise on cycling ergometer.

\section{Discussion}

It has been reported previously that carvedilol and other $\beta$-blockade agents produce deleterious effects on exercise measures, therefore, this study was established according to this biological effects, and to confirm that carvedilol differs from other types of $\beta$-adrenoceptor blockers, because it's also alpha - adrenoceptor blockade and antioxidant agent $[18,19]$.

Carvedilol produced insignificant effects on efforts of exercise in comparison with placebo, this supported by preview study which showed that vasodilator effect of 
carvedilol due to $\alpha$-blockade effect increased muscular blood flow and with antioxidant improve the motor-muscular activity [20], but this improvement don't showed in this study due to mall sample size. Regarding other exercise parameters, the calori not decreased which reflect the insignificant effect of carvedilol on muscle metabolism, the insignificant reduction in calori in comparison with placebo reflect the compensated vasodilator effect due to $\alpha_{1}$-adrenoceptor blocking effect with vasoconstrictor effects due to $\beta_{2}$-blocking [21]:

Moreover, carvedilol is a lipid soluble agent produce central effect not related to $\beta$-adrenoceptor effects [22], therefore the central effect improve the psychomotor effect due to increase cerebral blood flow and nitric oxide releasing [23], all of these produce significant improvement in exercise when compared with other $\beta$-adrenoceptors blockade agent like propranolol and metoprolol [24].

During exercise the serum lactate level and catecholamine level increased, but in this study these not measured, this reflect the oxygen consumption and stimulatory effects of catecholamine, but this effect not dominant because catecholamine level will return to decrease and form U-shape curve during the exercise [25].

So the exercise parametes will progressively decreased, but when carvedilol was introduced prior to exercise it produce protective effect from inhibitory effect of lactate [26] and overstimulatory effect of catecholamine, therefore improve the exercise measure which perse showed insignificant reduction in most exercise parameters [27, 28].

Carvedilol antioxidant effect regarded as the major effect on exercise measures that has protective effect from free radical radicals, also nitric oxide secretion from the vascular endothelium produced augmented effect on central and motor activity during exercise so prevented deleterous effect of $\beta$-adrenoceptor blockade [29, 30].

\section{Conclusions}

Carvedilol is not like other $\beta$-blockade agents in producing fatigue, but instead it produced insignificant effect on exercise parameters, this not related to $\beta$-adrenoceptor effect but related to nitric oxide donor effect and the major one is antioxidant effect.

\section{References}

[1] Blaufarb I, Pfeifer TM, Frishman WH: Beta-blockers: "Drug interaction of clinical significance". Drug Saf 2005; 13:359.

[2] Brantigan CO, Brantigan TA, Joseph N: "Effect of beta blockade and beta stimulation on stage fright". Am J Med 1999; 72:88.

[3] Bristow MR: "Mechanism of action of $\beta$-blocking agents in heart failure". Am J cardiol 2001; 80 (suppl 11 A) 26:221-223

[4] Feuerstein GZ, Ruffolo R.R.: "Carvedilol, a novel vasodilating $\beta$-blocker with the potential for cardiovascular organ protection". Eur Heart J 2002; 17 (suppl B): 24 .

[5] Freementle $\mathrm{N}$ et al: "Beta blockade after myocardial infarction: systemic review and meta regression analysis": BMI 2004; 318:1730.

[6] Frishman WH: "Carvedilol."N Engl J Med 2001; 339:1759.

[7] Gengo FM, Huntoon L, Mc Hugh WB: "Lipid soluble and water soluble beta blockers: Comparison of the central nervous effect". Arch Intern Med 1999; 147:39.

[8] Gold EH et al: "Synthesis and comparison of some cardiovascular properties of stereoisomers of labetolol". J Med chem. 1998; 25:1363.

[9] Goldstein S: "Beta blockers in hypertensive and coronary heart disease." Arch Intern Med (2007) 156:12-67.

[10]Hampton JR: "Choosing the right betablocker": A guide to selection. Drugs 2000; 48: 549.

[11]Fitzgerald JD: "Do partial agonist betablocker have improved clinical utility?" Cardiovascular Drugs Ther 2003; 7:303.

[12]Nickerson $M$ : "The pharmacology of adrenergic blockade." Pharmacol. Rev. (1982); 1:27.

[13] Teerlink JR, Massie BM: "Beta adrenergic blocker mortality trial in congestive heart failure." Am. J. cardiol. 2001; 84 (suppl 9 B):94 R. 
[14]Ohlstein EH et al:" Carvedilol, a cardiovascular drug, Prevents vascular smooth muscle cell proliferation, migration, and neointimal formation following vascular injury." Proc. Natl. Acad. Sci. USA. 2003; 90:6189.

[15] Vanzwieten PA: "An overview of the pharmacodynamic properties and therapeutic potential of combined alphaand Beta-adrenoceptors antagonist." Drugs 2001; 45:509-50.

[16] Yedinak KC:" Formulary consideration in selection of beta blockers." Pharmacoeconomics 2004; 4:104-109.

[17] Serwach N, Marino FE, Hilder M, Cannon J, Kay D." hydratin and exercise, Heat stress." http : // www. Ausport. gov. au/ fulltext/2004assms/paper/KAY1.

[18] Maebarba C, Ohtani H, Sugahara H et al. "Nightmere and panic disorders associated with carvedilol overdose". Ann Pharm. 2002; 36 (11): 1736 - 1740.

[19]Lord SR. "Physiologic, psychologic and health predictors of 6 min. walk performance in older people." Arch Phys Med Rehabil. 2002; 83 (7): 907 - 911.

[20]Levitt D. and Gutin MS "Effect of exercise on psychomotor performance" Med - Brit 1971; 81 (2):513 - 513.

[21]Freeman GL. "Facilitative and inhibitory effect of muscle tension upon performance", American Job phys. 1981; 26: $602-608$.

[22]Emery CF, Huppert FA, Schein RL. "Relationship among age, exercise, health, and cognitive function in a British sample". Erontologist. 1995; 35 (3):378 385.

[23] Collardeau K steven J, Kansarji M. "Physiological response and psychomotor performance in runners." Brit Med J. 2001; 841(1):213 - 216.

[24]Cunnigham FG. "Hypertension and $\beta$ blockers," British J. clin pharmacol 1984; 18:453455-.

[25]Caretti DM. "Cognitive performance and mood during respirator wear and exercise", Am Ind Hyg Assoc J. 1999; 60(2): $213-18$.

[26]Binder EF, Storandt M, Briges SJ. "The relation between psychometric test performance and physical performance" J
Gerontol A Bio Sci. Med Sci. 2001; 55(9):301 -305.

[27] Beversdorf DQ: "Central beta-adrenergic modulation of cognitive flexibility." Neuroreport 2002; 13(18 )17-19

[28]Bedi J and Gong H. "Enhancement of exercise performance with $\beta$-blocker", Can J sport Sci. 2003; 13(8):213 - 216.

[29] Basal D.: "Effect of selective $\beta$-blockers on dynamic of myocardial contractility function" New Eng. J. of Medicine. 2000; 82(1):213 -215.

[30]Buchsbaum M and Callaway E. "Influence of respiratory cycle on simple exercise, perceptual and Motor skill" British Medical Journal 2001; 20(1):101 - 105.

$$
\begin{aligned}
& \text { الخلاصة } \\
& \text { أستهدفت الدراسة معرفة تأثثر عقار الكارفيدولول على } \\
& \text { مفردات وأجزاء التمارين الرياضية. } \\
& \text { أجريت الدراسة على } 54 \text { منطوعاً } 19 \text { أناث و } 35 \text { ذكور } \\
& \text { من كلية الطب الجامعة المستتصرية. كل واحد من لند } \\
& \text { المتطوعين يجري التمارين الرياضية على جهاز الدراجة } \\
& \text { الاككترونية ومدة الاجهاد للشخص الواحد قبل وبعد أخذ عقار } \\
& \text { الكارفيدولول بجرعة } 6.25 \text { ملغم. } \\
& \text { أظهرت نتائج هذه الدراسة بان الكارفيدولول لايشبه } \\
& \text { مسدات مستقبلات بيتا التي كانت تؤدي الى تعب أثناء وبعد } \\
& \text { التمارين وان هذا العقار لايؤدي الى تعب واء عياء عند التمارين } \\
& \text { الرياضية. }
\end{aligned}
$$

